\title{
HAK-HAK KAUM BURUH JANGAN TERBLENGGU OLEH PEMASUNGAN KEPENTINGAN PEMILIK MODAL (Kepastian Hukum Lewat Undang-Undang Nomor: 13/2013 Tentang Ketenagakerjaan) ${ }^{1}$
}

\author{
Oleh : Ali Imron \\ Dosen Fakultas Hukum Universitas Pamulang
}

Email:

\begin{abstract}
Abstrak
Ketenagakerjaan berasal dari kata tenaga kerja, yang dalam Pasal 1 angka 2 UU No. 13 tahun 2003 tentang Ketenagakerjaan yaitu "Tenaga kerja adalah setiap orang yang mampu melakukan pekerjaan guna menghasilkan barang dan/atau jasa baik untuk memenuhi kebutuhan sendiri maupun untuk masyarakat." Sedangkan pengertian dari ketenagakerjaan sesuai dengan Pasal 1 angka 1 UU No. 13 tahun 2003 tentang Ketenagakerjaan adalah "Ketenagakerjaan adalah segala hal yang berhubungan dengan tenaga kerja pada waktu sebelum, selama, dan sesudah masa kerja." Demi meningkatkan taraf hidup maka perlu dilakukan pembangunan diberbagai aspek. Tidak terkecuali dengan pembangunan ketenagakerjaan yang dilakukan atas asas keterpaduan melalui koordinasi fungsional lintas sektoral pusat dan daerah. Dalam hal ini maksudnya adalah asas pembangunan ketanagakerjaan berlandaskan asas pembangunan nasional terkhusus asas demokrasi pancasila, asas adil, dan merata.
\end{abstract}

Kata Kunci:Hak-Hak Buruh, Pemilik Modal

\begin{abstract}
Employment comes from the workforce, which in Article 1 paragraph 2 of Law No. 132003 Manpower is "Manpower is every person who is able to work in order to produce goods and / or services, both for subsistence and for the community." While understanding of labor in accordance with Article 1 paragraph 1 of Law No. 132003 Manpower is "Employment is everything related to the workforce at a time before, during, and after the work period." In order to improve the standard of living it is necessary to the development of various aspects. No exception to the manpower development is done on the principle of integration through functional coordination across sectors and regional center. In this case the intention is Ketanagakerjaan construction principle based on the principal of national development especially its principle of Pancasila democracy, the principle of fair and equitable.
\end{abstract}

${ }^{1}$ Naskah diterima tanggal 14 Maret 2016, direvisi: 3 April 2016, disetujui untuk terbit 23 Mei 2016 dalam Volume 3 No.1 Juli 2016 
Keywords: Labor Rights, Own Capital

\section{A. Latar Belakang}

Dalam rangka mengejar pertumbuhan ekonomi, salah satunya melalui industrialisaasi, membawa akibat meletakkan posisi pemilik modal sebagai pelopor dan basis pendukung bagi keberhasilan pembangunan nasional, sebaliknya menempatkan pekerja pada posisi pemancing sektor penarik investasi sehingga nilai pekerja Indonesia lebih rendah daripada nilai pekerja luar negeri. Kebijakan pemerintah di bidang ketenagakerjaan seolah-olah kurang memperhatikan nasib pekerja. Hal ini ditunjang dengan adanya doktrin stabilitas yang semakin memperlemah posisi tawar buruh.

Keadaan ini menimbulkan adanya kecenderungan majikan untuk berbuat sewenang- wenang kepada pekerja/buruhnya. Buruh dipandang sebagai obyek. Buruh dianggap sebagai faktor ektern yang berkedudukan sama dengan pelanggan pemasok atau pelanggan pembeli yang berfungsi menunjang kelangsungan perusahaan dan bukan faktor intern sebagai bagian yang tidak terpisahkan atau sebagai unsur konstitutip yang menjadikan perusahaan. ${ }^{2}$

Majikan dapat dengan leluasa untuk menekan pekerja/buruhnya untuk bekerja secara maksimal, terkadang melebihi kemampuan kerjanya. Misalnya majikan dapat menetapkan upah hanya maksimal sebanyak upah minimum propinsi yang ada, tanpa melihat masa kerja dari pekerja itu. Seringkali pekerja dengan masa kerja yang lama upahnya hanya selisih sedikit lebih besar dari upah pekerja yang masa kerjanya kurang dari satu tahun. Majikan enggan untuk meningkatkan atau menaikkan upah pekerja meskipun terjadi peningkatan hasil produksi dengan dalih bahwa takut diprotes oleh perusahaan-perusahaan lain yang sejenis.

2 HP Rajagukguk, Peran serta pekerja dalam pengelolaan perusahaan (codetermination), (Jakarta: Makalah Fakultas Hukum Universitas Indonesia, 2000), hal. 3. 
Secara sosiologis kedudukan buruh adalah tidak bebas. Sebagai orang yang tidak mempunyai bekal hidup lain daripada itu, ia terpaksa bekerja pada orang lain. Majikan inilah yang pada dasarnya menentukan syarat-syarat kerja. ${ }^{3}$ Mengingat kedudukan pekerja yang lebih rendah daripada majikan maka perlu adanya campur tangan pemerintah untuk memberikan perlindungan hukumnya. Perlindungan hukum menurut Philipus.

Selalu berkaitan dengan kekuasaan. Ada dua kekuasaan yang selalu menjadi perhatian yakni kekuasaan pemerintah dan kekuasaan ekonomi. Dalam hubungan dengan kekuasaan pemerintah, permasalahan perlindungan hukum bagi rakyat (yang diperintah), terhadap pemerintah (yang memerintah). Dalam hubungan dengan kekuasaan ekonomi, permasalahan perlindungan hukum adalah perlindungan bagi silemah (ekonomi) terhadap si kuat (ekonomi), misalnya perlindungan bagi pekerja terhadap pengusaha. ${ }^{4}$

Perlindungan hukum bagi buruh sangat diperlukan mengingat kedudukannya yang lemah. Disebutkan oleh Zainal Asikin, yaitu : Perlindungan hukum dari kekuasaan majikan terlaksana apabila peraturan perundangundangan dalam bidang perburuhan yang mengharuskan atau memaksa majikan bertindak seperti dalam perundang-undangan tersebut benar-benar dilaksanakan semua pihak karena keberlakuan hukum tidak dapat diukur secara yuridis saja, tetapi diukur secara sosiologis dan filosofis. ${ }^{5}$

Bruggink membagi keberlakuan hukum menjadi tiga, yaitu keberlakuan faktual, keberlakuan normatif dan keberlakuan evaluatif/material. Keberlakuan faktual yaitu kaidah dipatuhi oleh para warga masyarakat/efektif kaidah diterapkan dan ditegakkan oleh pejabat hukum; keberlakuan normatif yaitu kaidah cocok dalam sistim hukum herarkis, keberlakuan evaluatif yaitu secara empiris kaidah tampak diterima, secara filosofis kaidah memenuhi sifat mewajibkan karena isinya. ${ }^{6}$

${ }^{3}$ Ibid, hal. 4.

${ }^{4}$ Philipus M Hadjon, Perlindungan hukum dalam negara hukum Pancasila, makalah disampaikan pada symposium tentang politik, hak asasi dan pembangunan hukum dalam rangka Dies Natalis XV/ Lustrum VIII, Universitas Airlangga, 3 November, 1994. hal. 4.

5 Asikin, Zainal, et.al. Dasar-dasar hukumperburuhan, Raja Grafindo Persada, Jakarta. 1993, hal. 5.

${ }^{6}$ Bruggink, JJH, alih bahasa Arief Sidharta, Refleksi tentang hukum, Citra Aditya Bakti, Bandung, 1996, hal. 157. 
Dari uraian di atas maka dapat ditarik permasalahan yaitu bagaimana bentuk perlindungan hukum bagi pekerja yang di putus hubungan kerjanya oleh majikan karena melakukan kesalahan berat. Selain itu juga bagaimana upaya hukum yang dapat dilakukan oleh pekerja apabila pekerja tidak mendapatkan haknya sesuai dengan ketentuan yang berlaku.

\section{B. Rumusan Masalah}

Dalam penulisan ini, maka yang menjadi dasar kajian permasalahan adalah membatasi hanya pada ruang lingkup terkait dengan pandangannya terhadap undang-undang No. 13 tahun 2003 tentang Ketenagakerjaan, dan bagaimana mekanisme undang-undang tersebut dalam memberikan perlindungan atau keberpihakkannya terhadap pekerja yang mengalami pemutusan hubungan kerja (PHK). Sehingga persoalan yang mendasar adalah:

1. Apakah hak-hak kaum buruh/pekerja terpasung oleh kepentingan pemilik modal?

2. Bagaimanakah kepastian hukum dalam UU Nomor: 13 tahun 2003, tentang Ketenagakerjaan terhadap perlindungan hak-hak buruh/pekerja?

Maka hal yang demikian, kiranya penulis memiliki anggapan atau pandangan bahwa kajian atau pembahasan kajian ini akan mengkrucut pada titik persoalan yang sudah termaktub dalam judul makalah tersebut. Dan sehingga kiranya bisa dipahami oleh para pihak.

\section{Pembahasan}

\section{Kebijakan Pemerintah di Bidang Ketenagakerjaan}

Pemerintah telah menetapkan kebijakan dibidang ketenagakerjaan yang dirumuskan dalam UU No. 13 tahun 2003. Berdasarkan ketentuan pasal 2 UU No. 13 tahun 2003 pembangunan ketenagakerjaan berlandaskan Pancasila dan Undang- Undang Dasar Republik Indonesia Tahun 1945. Pembangunan ketenagakerjaan dilaksanakan dalam rangka pembangunan manusia Indonesia seutuhnya. Oleh sebab itu pembangunan ketenagakerjaan dilaksanakan untuk 
mewujudkan manusia dan masyarakat Indonesia yang sejahtera, adil, makmur dan merata baik materiil maupun spiritual.

Selanjutnya, berdasarkan ketentuan pasal 3 UU No. 13 Tahun 2003 pembangunan ketenagkerjaan diselenggarakan atas asas keterpaduan dengan melalui koordinasi fungsional lintas sektoral pusat dan daerah. Hal ini dijelaskan lebih lanjut dalam penjelasannnya, yaitu: Asas pembangunan ketenagakerjaan pada dasarnya sesuai dengan asas pembangunan nasional, khususnya asas demokrasi Pancasila serta asas adil dan merata. Pembangunan ketenagakerjaan mempunyai banyak dimensi dan keterkaitan dengan berbagai pihak yaitu antara pemerintah, pengusaha dan pekerja/buruh. Oleh sebab itu, pembangunan ketenagakerjaan dilaksanakan secara terpadu dalam bentuk kerja sama yang saling mendukung.

Tujuan pembangunan ketenagakerjaan berdasarkan ketentuan pasal 4 UU No. 13 Tahun 2003 adalah :

a) memberdayakan dan mendayagunakan tenaga kerja secara optimal dan manusiawi;

b) Mewujudkan pemerataan kesempatan kerja dan penyediaan tenaga kerja yang sesuai dengan kebutuhan pembangunan nasional dan daerah;

c) memberikan perlindungan kepada tenaga kerja dalam mewujudkan kesejahteraan dan;

d) meningkatkan kesejahteraan tenaga kerja dan keluarganya

Pemberdayaan dan pendayagunaan tenaga kerja merupakan suatu kegiatan yang terpadu untuk dapat memberikan kesempatan kerja seluas-luasnya bagi tenaga kerja Indonesia. Melalui pemberdayaan dan pendayagunaan ini diharapkan tenaga kerja Indonesia dapat berpartisipasi secara optimal dalam pembangunan nasional, namun dengan tetap menjunjung nilai-nilai kemanusiaannya. Pemerataan kesempatan kerja harus diupayakan di seluruh wilayah negara kesatuan Republik Indonesia sebagai satu kesatuan pasar kerja dengan memberikan kesempatan yang sama untuk memperoleh pekerjaan bagi seluruh tenaga kerja Indonesia sesuai dengan bakat, minat dan kemampuannya. 
Demikian pula pemerataan penempatan tenaga kerja perlu diupayakan agar dapat mengisi kebutuhan di seluruh sektor dan daerah.

Penekanan pembangunan ketenagakerjaan pada pekerja mengingat bahwa pekerja adalah pelaku pembangunan. Berhasil tidaknya pembangunan teletak pada kemampuan, dan kualitas pekerja. Apabila kemampuan pekerja (tenaga kerja) tinggi maka produktifitas akan tinggi pula, yang dapat mengakibatkan kesejahteraan meningkat. Tenaga kerja menduduki posisi yang strategis untuk meningkatkan produktifitas nasional dan kesejahteraan masyarakat.

\section{Bentuk Perlindungan Hukum Bagi Pekerja yang di PHK}

Sebelum membahas tentang perlindungan hukum bagi pekerja yang di putus hubungan kerjanya, perlu dikaji tentang hubungan kerja. Berdasarkan ketentuan pasal 1 angka 15 Undang-Undang No.13 Tahun 2003 pengertian hubungan kerja yaitu "Hubungan antara pengusaha dengan pekerja/buruh berdasarkan perjanjian kerja, yang mempunyai unsur pekerjaan,upah dan perintah”. Hubungan kerja terjadi setelah adanya perjanjian kerja antara buruh dan majikan, yaitu suatu perjanjian dimana pihak kesatu, buruh, mengikatkan diri untuk bekerja dengan menerima upah pada pihak lainnya, majikan, yang mengikatkan diri untuk mempekerjakan buruh itu dengan membayar upah. "Pada pihak lainnya” mengandung arti bahwa pihak buruh dalam melakukan pekerjaan itu berada di bawah pimpinan pihak majikan. ${ }^{7}$

Hubungan kerja dilakukan oleh subyek hukum. Subyek hukum yang terikat dalam hubungan kerja ini adalah pengusaha dan pekerja. Pengertian pekerja/buruh berdasarkan pasal 1 angka 3 Undang-Undang No. 13 Tahun 2003 yaitu "Setiap orang yang bekerja dengan menerima upah atau imbalan dalam bentuk lain”. Undang-Undang No.13 Tahun 2003 membedakan pengertian antara pengusaha, pemberi kerja dan perusahaan. Pasal 1 angka 4 UndangUndang No.13 Tahun 2003 pengertian pemberi kerja yaitu ”Orang perseorangan, pengusaha, badan hukum, atau badan-badan lainnya yang

\footnotetext{
${ }^{7}$ Iman Soepomo, Pengantar HukumPerburuhan, Djambatan, Jakarta: 1974, hal. 1.
} 
mempekerjakan tenaga kerja dengan membayar upah atau imbalan dalam bentuk lain. Pengertian pengusaha menurut pasal 1 angka 5 Undang-Undang No.13 Tahun 2003 adalah:

a) Orang perseorangan, persekutuan, atau badan hukum yang menjalankan suatu perusahaan bukan miliknya;

b) Orang perseorangan, persekutuan, atau badan hukum yang secara berdiri sendiri menjalankan perusahaan bukan miliknya;

c) Orang perseorangan, persekutuan, atau badan hukum yang berada di Indonesia mewakili perusahaan sebagaimana dimaksud dalam huruf a dan b yang berkedudukan di luar wilayah Indonesia.

Berdasarkan ketentuan pasal 1 angka 6 Undang-Undang No.13 Tahun 2003 pengertian perusahaan adalah:

a. Setiap bentuk usaha yang berbadan hukum atau tidak, milik orang perseorangan, milik persekutuan, atau milik badan hukum, baik milik swasta maupun milik negara yang mempekerjakan pekerja/buruh dengan membayar upah atau imbalan dalam bentuk lain;

b. Usaha-usaha sosial dan usaha-usaha lain yang mempunyai pengurus dan mempekerjakan orang lain dengan membayar upah atau imbalan dalam bentuk lain.

Hubungan antara pengusaha dengan pekerja di dalam melaksanakan hubungan kerja diharapkan harmonis supaya dapat mencapai peningkatan produktifitas dan kesejahteraan pekerja. Untuk itu, para pengusaha dalam menghadapi para pekerja hendaknya :

1) Menganggap para pekerja sebagai partner yang akan membantunya untuk menyukseskan tujuan usaha;

2) Memberikan imbalan yang layak terhadap jasa-jasa yang telah dikerahkan oleh partnernya itu, berupa penghasilan yang layak dan jaminan-jaminan sosial tertentu, agar dengan demikian pekerja tersebut dapat bekerja lebih produktif (berdaya guna); dan

3) Menjalin hubungan baik dengan para pekerjanya. ${ }^{8}$

8 Sunindhia, YW, dan Widayanti, Ninik, Masalah PHK dan Pemogokan, PT. Bina Aksara, Jakarta: 1988, hal. 129. 
Agar kedua belah pihak dapat melaksanakan hubungan kerja dengan baik, tanpa adanya tindakan sewenang-wenang dari salah satu pihak maka diperlukan adanya campur tangan dari pemerintah dalam bentuk peraturanperundang-undangan. Adanya peraturan perundang-undangan ditujukan untuk pengendalian. Baik pemberi pekerja maupun yang diberi pekerjaan, masingmasing harus terkendali atau masing-masing harus menundukkan diri pada segala ketentuan dan peraturan yang berlaku, harus bertanggungjawab dalam melaksanakan kegiatan masing-masing sesuai dengan tugas dan wewenangnya, hingga keserasian dan keselarasan akan selalu terwujud. ${ }^{9}$

Selama pelaksanaan hubungan kerja, tidak tertutup kemungkinan terjadi pemutusan hubungan kerja. Baik yang dilakukan atas inisiatif pengusaha atau atas inisiatif pekerja. Berdasarkan ketentuan pasal 1 angka 25 Undang-Undang No.13 Tahun 2003 pengertian pemutusan hubungan kerja yaitu "Pengakhiran hubungan kerja karena suatu hal tertentu yang mengakibatkan berkhirnya hak dan kewajiban antara pekerja/buruh dan pengusaha”. Berdasarkan ketentuan pasal 150 UU No. 13 Tahun 2003, Pemutusan hubungan kerja meliputi pemutusan hubungan kerja yang terjadi di badan usaha yang berbadan hukum atau tidak, milik orang perseorangan, milik persekutuan atau badan hukum, baik milik swasta maupun milik negara, maupun usaha-usaha sosial dan usaha-usaha lainnya yang mempunyai pengurus, dan mempekerjakan orang lain dengan membayar upah atau imbalan dalam bentuk lain. Pemutusan hubungan kerja memberikan pengaruh psychologis, ekonomis-finansiil bagi si pekerja beserta keluarganya dalam mempertahankan kelangsungan hidupnya. PHK harus diupayakan untuk dicegah. Pengusaha dilarang melakukan PHK apabila didasarkan pada alasan-alasan berdasarkan pasal 153 ayat (1) Undang-Undang No.13 Tahun 2003 yaitu :

${ }^{9}$ Kartasapoetra, G, dan Widianingsih, G, Rience, Pokok-pokok Hukum Perburuhan, Armico, Bandung: 1982, hal. 13. 
a. Pekerja/buruh berhalangan masuk kerja karena sakit menurut keterangan dokter selama waktu tidak melampaui 12(dua belas) bulan secara terusmenerus;

b. Pekerja/buruh berhalangan menjalankan pekerjaannya karena memenuhi kewajiban terhadap negara sesuai dengan ketentuan perundang-undangan yang berlaku;

c. Pekerja/buruh menjalankan ibadah yang diperintahkan agamanya;

d. Pekerja/buruh menikah;

e. Pekerja/buruh perempuan hamil, melahirkan, gugur kandungan atau menyusui bayinya;

f. Pekerja/buruh mempunyai pertalian darah dan/atau ikatan perkawinan dengan pekerja/buruh lainnya di dalam satu perusahaan, kecuali telah diatur dalam perjanjian kerja, peraturan perusahaan, atau perjanjian kerja bersama;

g. Pekerja/buruh mendirikan, menjadi anggota dan atau pengurus serikat pekerja/serikat buruh, pekerja/buruh melakukan kegiatan serikat pekerja/serikat buruh di luar jam kerja, atau di dalam jam kerja atas kesepakatan pengusaha, atau berdasarkan ketentuan yang diatur dalam perjanjian kerja, peraturan perusahaan, atau perjanjian kerja bersama;

h. Pekerja/buruh yang mengadukan pengusaha kepada yang berwajib mengenai perbuatan pengusaha yang melakukan tindak pidana kejahatan;

i. Karena perbedaan paham, agama, aliran politik, suku, warna kulit, golongan, jenis kelamin,kondisi fisik, atau status perkawinan;

j. Pekerja/buruh dalam keadaan cacat tetap, sakit akibat kecelakaan kerja, atau sakit karena hubungan kerja yang menurut surat keterangan dokter yang jangka waktu penyembuhannya belum dipastikan.

Apabila PHK tidak dapat dicegah atau dihindari, maka pekerja yang di PHK oleh majikan sesuai dengan alasan yang mendasari terjadinya PHK akan mendapatkan uang pesangon, penghargaan masa kerja dan uang ganti kerugian. Kesemuanya itu dimaksudkan berfungsi sebagai jaminan pendapatan. Pelaksanaan pemutusan hubungan kerja berhubungan dengan jaminan pendapatan (income security) bagi buruh yang kehilangan pekerjaan. Kiranya 
perlu diciptakan peraturan yang memuaskan mengenai tata cara pemutusan hubungan kerja dengan memperhatikan kepentingan pihak pengusaha dan pihak buruh serta mengadakan penyelesaian yang layak dan patut serta dijiwai oleh nilai-nilai luhur Pancasila. ${ }^{10}$

Berdasarkan ketentuan UU No. 13 Tahun 2003, pengusaha dapat melakukan PHK terhadap pekerja karena alasan-alasan sebagai berikut :

a) Pekerja melakukan kesalahan ringan;

b) Pekerja melakukan kesalahan berat;

c) Perusahaan tutup karena pailit;

d) Force majeur;

e) Adanya efisiensi;

f) Perubahan status, milik, lokasi dan pekerja menolak;

g) Perubahan status, milik, lokasi dan majikan menolak;

h) Pekerja sakit berkepanjangan dan mengalami cacat akibat kecelakaan kerja. $^{11}$

Alasan dapat dibenarkan adanya PHK menurut Ridwan Halim dan Sunindhia yaitu :

1. Menurutnya hasil produksi yang dapat pula disebabkan oleh beberapa faktor misalnya :

a. Merosotnya kapasitas produksi perusahaan yang bersangkutan.

b. Menurunnya permintaan masyarakat atas hasil produksi perusahaan yang bersangkutan.

c. Menurunnya persediaan bahan dasar.

d. Tidak lakunya hasil produksi yang lebih dahulu dilemparkan ke pasaran dan sebagainya, yang semua ini secara langsung maupun tidak langsung mengakibatkan kerugian.

2. Merosotnya penghasilan perusahaan, yang secara langsung mengakibatkan kerugian pula.

${ }^{10}$ Djumialdji, FX, dan Soejono, Wiwoho, Perjanjian Perburuhan dan Hubungan Perburuhan Pancasila, PT. Bina Aksara, Jakarta: 1987, hal. 88.

${ }^{11}$ Asri Wijayanti, 2002, “ Perlindungan Hukum bagi Buruh yang di PHK di Perusahaan Swasta”, Prespektif Hukum, Jurnal Ilmiah Fakultas Hukum Universitas Hang Tuah, 2002, vol.2 No. 2, hal. 63. 
3. Merosotnya kemampuan perusahaan tersebut membayar upah atau gaji atau imbalan kerja lain dalam keadaan yang sama dengan sebelumnya.

4. Dilaksanakan rasionalisasi atau penyederhanaan yang berarti pengurangan karyawan dalam jumlah besar dalam perusahaan bersangkutan. ${ }^{12}$

Alasan lain yang bersumber dari keadaan yang luar biasa, misalnya :

1. Karena keadaan perang yang tidak memungkinkan diteruskannya hubungan kerja;

2. Karena bencana alam yang menghancurkan tempat kerja dan sebagainya;

3. Karena perusahaan lain yang menjadi penyelenggara pekerjaan yang bersangkutan ternyata tidak mampu lagi meneruskan pengadaan lapangan pekerjaan selama ini ada. Sedangkan perusahaan atau majikan yang secara langsung mempekerjakan para karyawan selama ini hanyalah merupakan kuasa yang bertindak untuk dan atas nama perusahaan yang lain yang menjadi penyelenggara atau pengada lapangan pekerjaan tersebut;

4. Karena meninggalnya majikan dan tidak ada ahli waris yang mampu melanjutkan hubungan kerja denga karyawan yang bersangkutan. ${ }^{13}$

Alasan PHK itu di dalam prakteknya ada yang mengandung cacat yuridis, dalam arti ada hal-hal yang tidak benar di dalam dasar surat keputusan PHK oleh majikan. ${ }^{14}$

Pemutusan hubungan kerja yang tidak layak, antara lain :

a. Jika antara lain tidak menyebutkan alasannya atau.

b. Jika alasannya PHK itu dicari-cari atau alasannya palsu.

c. Jika akibat pemberhentian itu adalah lebih berat dari pada keuntungan pemberhentian itu bagi majikan,atau.

${ }^{12}$ Halim, A Ridwan dan Gultom, Sri Subiandini, Sari Hukum Perburuhan Aktual, Pradnya Paramita, Jakarta: 1987, hal. 15.

${ }^{13}$ Sunindhia, Op.cit, hal. 23.

${ }^{14}$ Asri Wijayanti, Op.Cit, hal. 8. 
d. Jika buruh diperhentikan bertentangan dengan ketentuan dalam Undang-Undang atau kebiasaan mengenai susunan staf dan tidak alasan penting untuk tidak memenuhi ketentuan-ketentuan itu. ${ }^{15}$

Apabila alasan PHK tidak dapat dibenarkan maka akan berakibat PHK itu dapat dibatalkan. Sanksi atau hukuman bagi pemutusan hubungan kerja yang tidak beralasan yaitu :

a. Pemutusan tersebut adalah batal dan pekerja yang bersangkutan harus ditempatkan kembali pada kedudukan semula.

b. Pembayaran ganti rugi kepada pekerja tersebut. Dalam hal ini pekerja berhak memilih antara penempatan kembali atau mendapatkan ganti rugi. ${ }^{16}$

Pada garis besarnya pemutusan hubungan kerja dapat dibagi dalam empat golongan yaitu :

a. Pemutusan hubungan kerja karena hukum. Jika hubungan kerja yang diadakan untuk waktu tertentu, dan waktunya tersebut telah habis atau berakhir, maka pemutusan hubungan kerja dalam hal ini tidak diperlukan ijin. Hal demikian berarti putus dengan sendirinya, karena hukum.

b. Pemutusan hubungan kerja karena keputusan pengadilan. Pemutusan hubungan kerja oleh Pengadilan ialah pemutusan dengan melalui yang berwenang di Pengadilan atas permintaan yang bersangkutan, yang berdasarkan alasan-alasan penting.

c. Pemutusan hubungan kerja karena kehendak pekerja. Meliputi karena alas an mengundurkan diri atau alas an mendesak. Hal ini sesuai dengan pasal 169 ayat (1) Undang-Undang No.13 Tahun 2003 yaitu :pekerja/buruh dapat mengajukan permohonan pemutusan hubungan kerja kepada lembaga penyelesaian perselisihan hubungan industrial dalam hal pengusaha melakukan perbuatan sebagai berikut:

a. menganiaya, menghina secara kasar atau mengancam pekerja/buruh;

b. membujuk dan/atau menyuruh pekerja/buruh untuk melakukan perbuatan yang bertentangan dengan peraturan perundangan-undangan;

\footnotetext{
${ }^{15}$ Op.cit, hal. 29.

${ }^{16}$ Kertosaputro, Op.cit, hal. 287.
} 
c. tidak membayar upah tepat pada waktu yang telah ditentukan selama 3 (tiga) bulan berturut-turut atau lebih

d. tidak melakukan kewajiban yang telah dijanjikan kepada pekerja/buruh;

e. memerintahkan pekerja/buruh untuk melaksanakan pekerjaan di luar yang diperjanjikan; atau

f. memberikan pekerjaan yang membahayakan jiwa, keselamatan, kesehatan dan kesusilaan pekerja/buruh, sedangkan pekerjaan tersebut tidak dicantumkan pada perjanjian kerja.

d. Pemutusan hubungan kerja karena kehendak majikan. Pemutusan hubungan atas kehendak majikan adalah harus disertai ijin dari P4Daerah atau P4 Pusat selama lembaga penyelesaian perselisihan hubungan industrial belum terbentuk. Kriteria kesalahan berat yang dapat dijadikan dasar oleh majikan dalam memutus hubungan kerjanya dengan pekerja diatur dalam pasal 158 ayat (1) Undang-Undang No.13 Tahun 2003.

\section{Hak-hak Bagi Pekerja Yang di PHK}

Apabila PHK tidak dapat dihindari, maka sesuai dengan alasan yang mendasari terjadinya PHK maka pengusaha diwajibkan membayar uang pesangon, dan atau uang penghargaan masa kerja yang disesuaikan dengan masa kerja serta uang penggantian hak.

Ketentuan uang pesangon berdasarkan pasal 156 ayat (2) Undang-Undang 13 Tahun 2003 yaitu :

a. Masa kerja kurang dari 1 tahun, 1 bulan upah :

a. Masa kerja 1 tahun atau lebih tetapi kurang dari 2 tahun, 2 bulan upah;

b. Masa kerja 2 tahun atau lebih tetapi kurang dari 3 tahun, 3 bulan upah;

c. Masa kerja 3 tahun atau lebih tetapi kurang dari 4 tahun, 4 bulan upah;

d. Masa kerja 4 tahun atau lebih tetapi kurang dari 5 tahun, 5 bulan upah;

e. Masa kerja 5 tahun atau lebih tetapi kurang dari 6 tahun, 6 bulan upah;

f. Masa kerja 6 tahun atau lebih tetapi kurang dari 7 tahun, 7 bulan upah;

g. Masa kerja 7 tahun atau lebih tetapi kurang dari 8 tahun, 8 bulan upah;

h. Masa kerja 8 tahun atau lebih, 9 bulan upah. 
Ketentuan uang penghargaan masa kerja berdasarkan pasal 156 ayat (3) UndangUndang No. 13 Tahun 2003 yaitu :

a. Masa kerja 3 tahun atau lebih tetapi kurang dari 6 tahun, 2 bulan upah;

b. Masa kerja 6 tahun atau lebih tetapi kurang dari 9 tahun, 3 bulan upah;

c. Masa kerja 9 tahun atau lebih tetapi kurang dari 12 tahun, 4 bulan upah;

d. Masa kerja 12 tahun atau lebih tetapi kurang dari 15 tahun, 5 bulan upah;

e. Masa kerja 15 tahun atau lebih tetapi kurang dari 18 tahun, 6 bulan upah;

f. Masa kerja 18 tahun atau lebih tetapi kurang dari 21 tahun, 7 bulan upah;

g. Masa kerja 21 tahun atau lebih tetapi kurang dari 24 tahun, 8 bulan upah;

h. Masa kerja 24 tahun atau lebih, 10 bulan upah.

Uang penggantian hak yang seharusnya diterima berdasarkan pasal 156 ayat (4) Undang-Undang No. 13 Tahun 2003 meliputi :

a. Cuti tahunan yang belum diambil dan belum gugur;

b. Biaya atau ongkos pulang untuk pekerja/buruh dan keluarganya ke tempat dimana pekerja/buruh diterima bekerja;

c. Penggantian perumahan serta pengobatan dan perawatan ditetapkan $15 \%$ dari uang pesangon dan/atau uang penghargaan masa kerja yang memenuhi syarat;

d. Hal-hal lain yang ditetapkan dalam perjanjian kerja, peraturan perusahaan atau perjanjian kerja bersama.

\section{Bentuk Perlindungan Hukum Bagi Pekerja Karena Melakukan} Kesalahan Berat

Berdasarkan ketentuan pasal 158 ayat (1) Undang-Undang No.13 Tahun 2003 pengusaha dapat memutuskan hubungan kerja terhadap pekerja/buruh dengan alasan pekerja/buruh telah melakukan kesalahan berat sebagai berikut:

1. melakukan penipuan, pencurian atau penggelapan barang dan/atau uang milik perusahaan;

2. memberikan keterangan palsu atau yang dipalsukan sehingga merugikan perusahaan; 
3. mabuk,meminum minuman keras yang memabukkan, memakai dan/atau mengedarkan narkotika, psikotropika dan zat aditiktif lainnya di lingkungan kerja;

4. melakukan perbuatan asusila atau perbuatan perjudian di lingkungan kerja;

5. menyerang, menganiaya, mengancam, atau mengintimidasi teman sekerja atau pengusaha di lingkungan kerja;

6. membujuk teman sekerja atau pengusaha untuk melakukan perbuatan yang bertentangan dengan peraturan perundang-undangan;

7. dengan ceroboh atau sengaja merusak atau membiarkan dalam keadaan bahaya barang milik milik perusahaan yang menimbulkan kerugian bagi perusahaan;

8. dengan ceroboh atau sengaja membiarkan teman sekerja atau pengusaha dalam keadaan bahaya di tempat kerja;

9. membongkar atau membocorkan rahasia perusahaan yang seharusnya dirahasiakan kecuali untuk kepentingan negara atau melakukan perbuatan lainnya di lingkungan perusahaan yang diancam pidana penjara 5 (lima) tahun atau lebih.

Sebelas kriteria kesalahan berat yang diatur dalam pasal 158 ayat (1) UU No. 13 Tahun 2003 itu pada dasarnya dapat disejajarkan dengan delict (perbuatan melanggar hukum) kejahatan, yang diatur dalam Buku kedua Wetboek van starfrecht. Diputuskannya pekerja telah melakukan kesalahan berat, haruslah didasarkan pada prosedur yang diatur dalam pasal 158 ayat (2) UU No. 13 Tahun 2003, yaitu :

a. pekerja/buruh tertangkap tangan;

b. ada pengakuan dari pekerja/ buruh yang bersangkutan, atau ;

c. bukti lain berupa laporan kejadian yang dibuat oleh pihak yang berwenang di perusahaan yang bersangkutan dan didukung oleh sekurang-kurangnya 2 (dua) orang saksi.

Tiga syarat yang ditetapkan dalam pasal 158 ayat (2) UU No. 13 Tahun 2003 harus bersifat kumulatif, tidak boleh alternatif. Maksudnya adalah kesemua syarat yang ditetapkan dalam pasal 158 ayat (2) UU No. 13 Tahun 2003 itu 
harus ada, tidak adanya salah satu syarat dari ketiga syarat itu menjadikan putusan pengusaha/majikan bahwa pekerja telah melakukan kesalahan berat tidak dapat diterima.

Syarat pertama yang menyebutkan bahwa pekerja/buruh telah tertangkap tangan maksudnya adalah pekerja telah dapat dibuktikan bersdasarkan adanya bukti awal bahwa ia telah melakukan salah satu perbuatan yang telah ditetapkan dalam pasal 158 ayat (1) UU No. 13 Tahun 2003. Ada bukti awal yang cukup untuk dinyatakan bahwa pekerja telah melakukan kesalahan berat. Syarat yang kedua yaitu adanya pengakuan dari pekerja/buruh yang bersangkutan bahwa ia telah melakukan perbuatan yang telah dituduhkan berdasarkan bukti awal pada saat tertangkap tangan. Pengakuan dari pekerja atau buruh itu dapat dibuat dalam bentuk lisan maupun bentuk tertulis. Untuk menjamin adanya kepastian hukum sebaiknya pengakuan dari pekerja/buruh yang bersangkutan dibuat dalam bentuk tertulis, lebih baik lagi apabila yang membuat adalah pekerja sendiri (dalam arti tidak dibuatkan oleh personalia sepertia yang terjadi di dalam praktek). Tentunya pembuatan surat pernyataan pengakuan telah melakukan salah satu dari perbuatan yang termasuk dalam kriteria kesalahan berat itu harus dibuat dengan kesadaran sendiri tidak dalam keadaan adanya paksaan, tekanan, atau tipu muslihat dari pengusaha/majikan ataupun dari pihak personalia. Intinya tidak boleh dibuat atas dasar adanya kebohongan.

Syarat yang ketiga adalah adanya bukti lain berupa laporan kejadian yang dibuat oleh pihak yang berwenang di perusahaan yang bersangkutan dan di dukung olh sekurang-kurangnya dua orang saksi. Syarat ketiga ini pada dasarnya merupakan kelanjutan dari telah dipenuhinya syarat pertama dan syarat kedua. Syarat ketiga pada hakekatnya memperkuat sayarat pertama dan syarat kedua. Hal ini berlainan dengan rumusan dari ketentuan pasal 158 ayat 2 yang dapat ditafsirkan hanya menentukan ketiga syarat itu sebagai syarat alternatif dan bukan sebagai syarat kumulatif (garis bawah dari penulis). Dikatakan secra penafsiran bahwa itu menunjukkan sebagai syarat alteranatif karena antara pasal 158 ayat (2) b dan pasal 158 ayat (2) c UU No. 13 Tahun 2003 menyebutkan kata atau bukan dan. Penggunaan kata dan dengan kata atau dalam konteks bahasa hukum membawa akibat yang berlainan. Seharusnya redaksional pasal 
158 ayat (2) UU No. 13 Tahun 2003 itu tertulis dan. Kekhawatiran akan terjadinya penyalahgunaan yang akan terjadi di masyarakat dapat dipahami. Mengingat apabila syarat yang terdapat dalam pasal 158 ayat (2) UU No. 13 Tahun 2003 dapat hanya dipakai salah satu saja. Misalnya A pekerja di PT X, pada saat akan pulang dan menjalani check body ( pemeriksaan oleh petugas keamanan di pintu keluar tempat kerja) kedapatan telah membawa barang milik perusahaan tanpa alas hak yang dapat dibenarkan. Atas dasar telah terpenuhinya syarat pertama yaitu pekerja telah tertangkap tangan dengan tanpa diikuti syarat kedua dan ketiga maka A saat itu juga dapat diPHK secara sepihak. Misalnya kenyataannya A tidak pernah mengambil barang milik perusahaan. Atau karena ada orang lain yang sengaja ingin mencelakakan A supaya ia dapat di PHK. Tidak adan gunanya apabila A bersikeras menolak tuduhan itu. Begitu juga apabila A tidak pernah mau mengakui bahwa ia telah mencuri apalagi mau membuat surat pengakuan bahwa ia telah mencuri. Kekurang cermatan dalam merumuskan norma hukum tanpa memahami konsep bahasa hukum memang dapat berpengaruh pada keberlakuan hukum. Apabila dilakukan analisis maka ketentuan pasal 158 ayat (2) UU No. 13 Tahun 2003 itu tidak memenuhi syarat keberlakuan yuridis dari Bruggink. Sebagai bahan telaah dapat diteliti kembali norma hukum PHK yang diatur dalam UU No. 12 Tahun 1964 tentang PHK di perusahaan swasta, yang dengan tegas menetapkan bahwa PHK. Hal itu tidak terdapat di dalam ketentuan UU No. 13 Tahun 2003, yang tidak mensyaratkan adanya izin bagi PHK karena pekerja telah melakukan kesalahan berat.

Apabila pekerja mengalami PHK karena telah melakukan kesalahan berat maka pekerja itu mempunyai hak sesuai dengan ketentuan pasal 158 ayat (3) dan ayat (4) Undang-Undang No. 13 Tahun 2003 yaitu : Pekerja / buruh yang diputus hubungan kerjanya berdasrkan alasan sebagaimana dimaksud dalam ayat (1) dapat memperoleh uang penggantian hak sebagaimana dimaksud dalam pasal 156 ayat (4). Bagi pekerja / buruh sebagaimana dimaksud dalam ayat (1) yang tugas dan fungsinya tidak mewakili kepentingan pengusaha secara langsung, selain uang penggantian hak sesuai dengan ketentuan pasal 156 ayat (4) diberikan uang pisah yang besarnya dan pelaksanaannya diatur dalam 
perjanjian kerja, peraturan perusahaan atau perjanjian kerja bersama. Ketentuan uang pisah memang belum ada peraturan pelaksananya. Dalam hal ini Apindo (Asosiasi Pengusaha Indonesia) menghimbau agar anggotanya yang terdiri dari para pengusaha memberikan uang pisah minimal sebesar satu bulan upah. Hal ini dilakukan dengan tujuan memberikan masukan pada pengusaha untuk segera merumuskan besarnya uang pisah yang dapat diberikan kepada pekerja bersama dengan serikat pekerja/buruh. Rumusan kesepakatan tentang besarnya uang pisah itu dapat dituangkan dalam perjanjian kerja bersama.

Contoh Kasus. A bekerja di PT X di bagian produksi dengan upah perbulan satu juta. Masa kerja A bekerja di PT X adalah selama 8 tahun 9 bulan. Akhir bulan lalu A tertangkap tangan telah mencuri barang milik perusahaan. Akhirnya diputuskan A harus di PHK karena melakukan kesalahan berat. Adapun hak yang diperoleh A dari PT X saat itu adalah uang penggantian hak yang sesuai dengan Pasal 161 ayat (3) Undang-Undang No. 13 Tahun 2003 dan uang pisah berdasarkan ketentuan pasal 158 ayat (4) UU No. 13 Tahun 2003.

Dari ketentuan yang telah ditetapkan oleh perusahaan X, maka A berhak menerima uang pisah sebesar Rp 1 juta di tambah dengan uang penggantian hak, yaitu penggantian pengobatan dan perumahan sebesar $15 \%$ x Rp 1 juta $=\mathrm{Rp}$ 150.0000. Jadi A mendapatkan hak karena adanya PHK dengan alasan telah melakukan kesalahan berat sebesar Rp. 1. 150.000 ditambah penggantian hak lainnya yang belum diterima (misalnya cuti tahunan yang belum diambil dan belum gugur ; biaya atau ongkos pulang untuk pekerja/buruh dan keluarganya ke tempat dimana pekerja/buruh diterima bekerja ; Keseluruhan hak itu tentu saja dapat diberikan oleh pengusaha apabila kesalahan berat yang dituduhkan kepada pekerja secara formil maupun secara material memang benar.

\section{Penutup}

\section{Kesimpulan}

Masyarakat memahami dengan jelas UU No. 13 tahun 2003 tentang Ketenagakerjaan yang terlihat jelas dengan cara masyarakat menanggapi berbagai ketentuan dan kekurangan dari UU Ketenagakerjaan tersebut. 
Masyarakat memahami dengan baik kurangnya perlindungan yang diberikan terhadap pekerja/buruh dari regulasi tersebut dan masih adanya celah untuk lahirnya masalah baru dalam ketenagakerjaan. Masyarakat menerima dengan baik terhadap UU No. 13 tahun 2003 tentang Ketenagakerjaan yang ditunjukkan dengan adanya niat masyarakat untuk melakukan perbaikan melalui revisi UU Ketenagakerjaan tersebut. Akibat lahirnya berbagai masalah di Indonesia terkait ketenagakerjaan. Maka ketenagakerjaan yang pada awalnya berada dalam ruang lingkup hukum privat maka pemerintah memandang hukum ketenagakerjaan itu bagian penting untuk diatur langsung oleh pemerintah sehingga dialihkan menjadi bagian dari hukum publik. Sedangkan tujuan dari UU No. 13 tahun 2003 tentang Ketenagakerjaan itu sendiri dituangkan dalam Pasal 4 UU No. 13 tahun 2003 tentang Ketenagakerjaan. Meski awalnya berbagai permasalahan sebelum lahirnnya UU No. 13 tahun 2003 tentang Ketenagakerjaan dapat diselesaikan. Namun ternyata setelah lahir UU tersebut malah melahirkan masalah baru dalam hal kurangnya perlindungan terhadap pekerja/buruh dan masih adanya celah lain untuk lahirnya masalah baru dalam ketenagakerjaan. UU Ketengakerjaan tersebut belum mengatur dengan jelas perlindungan terhadap pekerja/buruh yang selalu berada dipihak yang lemah dalam sebuah hubungan kerja.

Setiap pekerja/buruh yang di PHK oleh majikan karena melakukan kesalahan berat sesuai dengan ketentuan pasal 158 ayat (1) UU No. 13 Tahun 2003, harus disertai tiga syarat secara kumulatif. Syarat itu adalah bukti tertangkap tangan, pengakuan dari pekerja yang bersangkutan dan laporan pengusaha yang didukung 2 orang saksi. Apabila keputusan perusahaan melakukan PHK karena pekerja melakukan kesalahan berat dibenarkan oleh hukum maka pekerja harus mendapatkan uang penggantian hak dan uang pisah. Apabila hak diatas tidak dapat diperoleh oleh pekerja maka pekerja dapat melakukan upaya penyelesaian hukum secara sukarela melalui bipatrid atau secara wajib yang didahului lapor ke pegawai perantara untuk mendapatkan anjuran Kemenakertrans untuk mendapatkan hak Veto untuk dapat dilakukan fiat eksekusi di Pengadilan Negeri Hubungan Industrial (PPHI). Apabila tidak dilaksanakan maka dapat mengajukan KASASI di MA atau cara lainnya dapat 
dilakukan gugat ganti rugi ke Pengadilan Negeri berdasarkan pasal 1365 BW. Apabila pengadilan hubungan industrial yang dibentuk berdasarkan UU No. 2 Tahun 2004 sudah terbentu maka upaya hukum dapat dilakukan meliputi upaya bipartid, mediasi, konsiliasi, arbitrasi atau ke kepadilan hubungan industrial.

\section{Saran}

Pertama, Utuk mewujudkan keberpihakkan dan memiliki kecenderungan terhadap masalah dan kepentingan pekerja menjadi penting dan merupakan prioritas utama, maka arah kebijakan peningkatan iklim ketenagakerjaan harus ditujukan Kecendrungan Keberpihakkan Terhadap Tenaga Kerja agar hak-hak kaum buruh/pekerja dapat terlindungi. Kedua, pemerintah harus terus berupaya menyempurnakan dan mengkonsolidasikan program-program penciptaan kesempatan kerja dan mampu menciptakan regulasi yang jesas dengan terus berusaha untuk penyempurnaan berbagai upaya penciptaan kesempatan kerja yang dilakukan oleh pemerinta, sehingga undangundang tersebut bisa memberikan kepastian hukum terhadap kaum buruh/pekerja. 


\section{DAFTAR PUSTAKA}

Asikin, Zainal, 1993, et.al. Dasar-dasar hukumperburuhan, Raja Grafindo Persada, Jakarta

Asri Wijayanti, 2002, “ Perlindungan Hukum bagi Buruh yang di PHK di Perusahaan Swasta”, Prespektif Hukum, Jurnal Ilmiah Fakultas Hukum Universitas Hang Tuah.

Bruggink, JJH, 1987, alih bahasa Arief Sidharta, 1996, Refleksi tentang hukum, Citra Aditya Bakti, Bandung

Djumialdji, FX, dan Soejono, Wiwoho, Perjanjian Perburuhan dan Hubungan Perburuhan Pancasila, PT. Bina Aksara, Jakarta

HP Rajagukguk, 2000, Peran serta pekerja dalam pengelolaan perusahaan (co-determination), (Jakarta: Makalah Fakultas Hukum Universitas Indonesia

Halim, A Ridwan dan Gultom, Sri Subiandini, 1987, Sari Hukum Perburuhan Aktual, Pradnya Paramita, Jakarta Jakarta

Iman Soepomo, 1974, Pengantar HukumPerburuhan, Djambatan,

Indonesia. Undang-Undang Nomor 13 Tahun 2003 tentang Tenaga Kerja 
Kartasapoetra, G, 1992, Hukum Perburuhan di Indonesia Berdasarkan Pancasila, Sinar Grafindo, Jakarta

Sunindhia, YW, dan Widayanti, Ninik, 1988, Masalah PHK dan Pemogokan, PT. Bina Aksara, Jakarta

Philipus M Hadjon, 1994, Perlindungan hukum dalam negara hukum Pancasila, makalah disampaikan pada symposium tentang politik, hak asasi dan pembangunan hukum dalam rangka Dies Natalis XV/ Lustrum VIII, Universitas Airlangga

Kartasapoetra, G, dan Widianingsih, G, Rience, 1982, Pokok-pokok Hukum Perburuhan, Armico, Bandung

Undang-Undang, No.13 Tahun 2003 tentang Ketenagakerjaan (LN. Tahun 2003, No. 39, TLN, No. 4279)

Undang-Undang No. 2 Tahun 2004 tentang Penyelesaian Perselisihan hubungan Industrial. (LN Tahun 2004 No. 6, TLN No. 4356) 